\title{
EFFECTS OF COMPACTION, MOISTURE AND DEPTH ON THE PARAMETERS OF THE KOSTIAKOV EQUATION
}

\author{
EFECTOS DE LA COMPACTACIÓN, HUMEDAD Y \\ PROFUNDIDAD SOBRE LOS PARÁMETROS DE LA ECUACIÓN \\ DE KOSTIAKOV
}

\author{
Américo J. Hossne García, Jesús Méndez N., I.J. Smith, P. Velázquez, L.M. Leiva G., Alexander Gil
}

Universidad de Oriente, Núcleo Monagas, Departamento de Ingeniería Agrícola Campus Los Guaritos, Maturín, Estado Monagas, Venezuela.

Email: hossnegarciaamerico@gmail.com

\section{Información del artículo}

Tipo de artículo: Artículo original

Recibido:

22/05/2020

Aceptado:

05/05/2021

Licencia:

CC BY-NC-SA 4.0

Revista

ESPAMCIENCIA

12(1):56-68

DOI:

https://doi.org/10.51

260/revista_espamci

encia.v12i1.263

\begin{abstract}
This report consisted of studying the effects caused by the soil physical characteristic, in the presence of wetness variations and structures-texture fluctuations, to the Kostiakov constants. The objectives were to investigate the effects of wetness, soil depth, and compaction on the Kostiakov constants "a", and "b". The experimental unit consisted of nine polyvinyl cylinders. Statistical analysis under a randomized block design with three replications and three factors: wetness with five levels, soil depth (0-15, 15-30 and 45-60) and compaction with three levels ( 0,13 and 26 blows). The relation between the instantaneous infiltration versus compaction and bulk density were inversely proportional. The parameter "a" influenced infiltration more than "b". Soil texture and structure influenced "b" more than wetness. Wetness influenced "a" more than compaction and soil depth. Kostiakov parameters exposed physical relations to soil texture and structure.
\end{abstract}

Keywords: Surface response, proctor test, kostiakov equation theory analysis.

\section{Resumen}

Este reporte estudió los efectos causados por las características físicas del suelo, en presencia de las variaciones de la humedad y la textura-estructura fluctuante, a las constantes de Kostiakov. Los objetivos evaluaron los efectos de la humedad, profundidad y compactación sobre las constantes "a" y "b" de Kostiakov. La unidad experimental usó nueve cilindros. Análisis estadístico bajo diseño de bloques al azar con tres repeticiones y tres factores: humedad con cinco niveles, tres profundidades de suelo y compactación con tres niveles. Se concluyó que la relación entre la infiltración y compactación, infiltración y densidad aparente son inversamente proporcionales. El parámetro "a" influyó en la infiltración más que "b". La textura del suelo y la estructura influyeron en "b" más que la humedad. La humedad influyó más que la compactación y la profundidad del suelo en "a". Los parámetros mostraron relaciones físicas con la textura y estructura del suelo.

Palabras clave: Superficie de respuesta, método proctor, análisis teórico de la ecuación de kostiakov.

\section{INTRODUCTION}

This report considers to find out that the variance of soil physical and terra mechanics properties in the presence of soil wetness changes or drying and wetting conditions, may perturb Kostiakov parameters. According to Haghnazari et al. (2015) and Dingman, (2002) measurements must be collected during or close as possible to the irrigation event using a representative sample of the field area. Mara (2016) reported that pore diameter $\geq 30$ microns $(0.03 \mathrm{~mm})$ hold no water due to the effect of the attractive force of gravity. Kostiakov (1932) indicated that the equation is no longer applicable once the characteristic steady infiltration rate has been attained. Infiltration variability poses a significant problem for the performance of surface irrigation systems. Not only it reduces the existing and potential irrigation performance, but it also limits the ability to specify improved irrigation strategies. The nature of soil properties does not facilitate direct measurement of the infiltration function. Hence, 
there is a genuine need to estimate the parameters of the chosen infiltration function using measured field data. The objectives were to investigate the effects of wetness, soil depth and compaction on the constants "a" and "b" characteristic in the Kostiakov infiltration equation with a view of adapting this equation.

\section{Theory}

Poulovassilis et al., (1989) stated that many empirical or semi-empirical equations exist for describing the relationship between the cumulative infiltration and the infiltration time, during the process of vertical infiltration of water into the soil mass. Duru et al., (2005) suggested that Kostiakov was, apparently, the first to propose an empirical equation. One of the best-known models to assess the behavior of soil water infiltration is Kostiakov developed in 1932 (Kostiakov, 1932; Holzapfel and Matta, 2005; Forero, 2000; Weber and Apestegui, 2016). According to Ahuja et al., (2007) this equation applies only for early to intermediate infiltration times before gravity begins to dominate and the infiltration rate approaches a constant value. Kostiakov equation is valid when the infiltration rate is higher than the saturated hydraulic conductivity of the soil (Mazloom and Foladmand, 2013).

Kostiakov equation symbolized by Equation 1, "i" infiltration depth $(\mathrm{cm})$ (also known as total infiltration depth, or infiltration rate, or cumulative infiltration, or cumulative infiltration depth, or cumulative infiltration rate, or infiltrated water since the beginning of infiltration, or steady-state infiltration rate or infiltration time) by length/hour, and the elapsed time (t) since the start of infiltration minute or hour, "a" and " $b$ " are the fitting parameters (constant of empirical adjustment, a $>0$ and 0 $<$ b $<1$ ), "a" coefficient of infiltration rate, term that depends on the structure and soil conditions $(\mathrm{a}>1)$; considered as an index of soil structure stability, "b" dimensionless parameter ( 0 - 1 agricultural soil), a time exponent and is a negative value; considered a measure of first-rate of infiltration and structural condition of the soil (Magnus and Adindu, 2014).

$$
\mathrm{i}=\mathrm{a} * \mathrm{tb}(\mathrm{cm})
$$

Kostiakov equation linearization is done by both equation sides logarithms application. The infiltration " $i$ " is normally plotted versus time on a logarithm graph sheet (double-logarithmic scales) and the best-fit line obtained by the least-squares curve fitting technique. A plot of $\log (\mathrm{i})$ against $\log (\mathrm{t})$, gives a straight line whose slope gives the value of "b", while $\log (a)$ gives the intercept. The value of "a" is obtained from the anti-log(a) (Akinbile, 2010; Magnus and Adindu, 2014):

$$
\begin{gathered}
\log (\mathrm{i})=\log (\mathrm{a})+\mathrm{b}^{*} \log (\mathrm{t})(2) \\
\mathrm{a}=10 \log (\mathrm{a}) \text { equivalent to }=\log (10 \mathrm{a}) \text { because } \mathrm{a}= \\
\text { antilog(log(a))(3) }
\end{gathered}
$$

According to Saito et al., (2016) constant "b" has a negative and strong correlation. This constant does not have clear physical meaning, but when the " $b$ " value is small, the infiltration rate rapidly decreases with time. Thus, "b" values were particularly small where there are horizons of low permeability. These " $b$ " values enhanced the negative slope of the regression line. "a" measures infiltrability at the beginning of the infiltration process and results show that surface soil permeability was strongly correlated with the vegetation. Kincaid et al., (1969) found for three different soils (silt loam, sandy loam, and clay), that "a" ranged from 0.225 to 1.1 and " $b$ " from 0.458 to 0.669. According to Adindu et al., (2014); Al-Azawi (1985) and Moroke et al., (2009); "b" is accepted by most authors less than 1 (Al-Azawi, 1985; Moroke et al., 2009; Adindu et al., 2014). Since the infiltration decreased with time, the exponent " $b$ " considered negative; in this work varied $-1<\mathrm{b}<0$. Analyzing Equation 1, when time tends to infinity, as "b" is negative, " $i$ " would tend to zero instead of a constant value (different from zero). FubaraManuel and Otoko, (2015) found in loamy sandy soil in Nigeria, the values of "a", and "b", 0.62 and 0.01 correspondingly. Gosh, (1985) questioned, in the model, the value of " $b$ " between zero and one. Mathematically, he proved that the value of " $b$ " is greater than unity. Mbagwu, (1990) experimentally found that the value of "b" was consistently less than one. On real field plots, Roy and Gosh, (1982) reported that the infiltration rate was neither asymptotic with the time $(\mathrm{t})$ axis, nor attained a zero value. Musa and Adeoye, (2010) found values of " $b$ " that ranged from 0.37 to 1.79 , and the infiltration equations obtained for the soils were: $0.41 \mathrm{t} 1.38,0.41 \mathrm{t} 1.79,0.50 \mathrm{t} 0.37$, $0.42 \mathrm{t} 1.12$ and $0.53 \mathrm{t} 1.37$, soil structure was not included. Soils that have a very stable structure have values of " $b$ " greater than 0.6 and can reach 1.0 under conditions where gravity flow predominated (Rondón et al., 1980).

Concurring, Swartzendruber, and Huberty (1958) defined "a" as a measure of the average infiltration rate for the first unit time interval and " $b$ " as an indicator of the changes in the system of force with time; also, if "b" was close to 0.5 , assumed that capillary forces were controlling infiltration, and that deviation of " $b$ " from 0.5 was a measure of the relative importance of other forces and factors in controlling infiltration; similarly, gravity forces and hydraulic pressures, such as ponding, caused higher values for "b". Swartzendruber and Huberty, (1958) and Dixon, (1976) exhibited that "a" was storage during the first hour, and " $b$ " the ratio which reflected the degree of storage abatement during the first hour, $b=1$ indicated no abatement and $\mathrm{b}=0$ complete abatement; also manifested that the size of parameter " $b$ " was inversely related to the number and intensity of active infiltration decay 
processes, and "a" was simply product of the first-hour time-weighted means for the hydraulic conductivity and the hydraulic gradient by Darcy's law at the soil surface.

The derivative of Equation 1 yields the instantaneous infiltration rate (I) indicating the infiltration depth per unit time t. "I" represents the rates of change. The second derivative produces the acceleration rate. The infiltration depth rate units are generally in $\mathrm{cm} \cdot \mathrm{min}-1$, multiplied by 60 to convert to $\mathrm{cm} \cdot \mathrm{h}-1$. The differential represents an infinitely small change in the variable $i$. It represents the relationship between a continuously varying quantity and its rate of change:

$$
\begin{gathered}
I=\frac{d i}{d t}=b^{*} a * t^{b-1}(\mathrm{~cm} \cdot \min -1)(4) \\
d i=\left(b^{*} a^{*} t^{b-1}\right) d t
\end{gathered}
$$

To test the Kostiakov model is necessary to study the basic speed of entry or basic infiltration (least value of $f(t)$ in a finite time interval); defined as the value, when the rate of change of response for a standard period is $10 \%$ or less of its value; i.e., infiltration remains constant, after a certain period (Orjuela-Matta et al., 2010; Rode, 1965; Holzapfel and Matta, 2005; Villalobos, 2008):

$$
\begin{gathered}
\frac{d i}{d t}=-0.1^{*} i \\
I=-0.1^{*} a * t^{b} \Rightarrow \\
a^{*} b^{*} t^{b-1}=-0.1 * a * t^{b} \Rightarrow t=-10 * b \\
I_{B A}=a^{*}(-10 * b)^{b} \text { for } i=a^{*} t^{b}
\end{gathered}
$$

If basic infiltration IBA is in cm $\bullet$ min-1, multiplied by 60 , IBA is obtained in $\mathrm{cm} \bullet \mathrm{h}-1$. Equation 10 represents the time when the basic infiltration occurs.

$$
I_{B A}=a^{*}(-600 * b)^{b} \quad\left(\mathrm{~cm} \cdot \mathrm{h}^{1}\right)
$$

Equation 11 represents the infiltration depth; named also, steady-state infiltration rate.

$$
I_{I N T}=i=a^{*} t^{b}(\mathrm{~cm})
$$

Equation 12 represents the total accumulated infiltration (IAC) when integrating i concerning the time

$$
\begin{gathered}
\text { infinite sum of infinitesimal quantities. } \\
I_{A C}=\frac{a}{(b+1)} * t^{b+1} \mathrm{~cm} \cdot \mathrm{min}^{-1} \\
I_{A C}=\frac{a}{60 *(b+1)} * t^{b+1} \quad\left(\mathrm{~cm} \cdot \mathrm{h}^{-1}\right)
\end{gathered}
$$$$
I_{A C}=\int_{0}^{t} i^{*} d t=\int_{0}^{t} a^{*} t^{b} d t \text { An integral ponders an }
$$

Equation 13 represents the average o medium infiltration

$$
\mathrm{I}_{M E D}=\frac{a * t^{b}}{(b+1)}(\mathrm{cm})
$$

The parameters "a" and "b" are site-specific since they depend on texture, structure, vegetative cover, infiltrometer type, moisture condition, rainfall intensity, permeability, soil surface conditions and properties (AlAzawi, 1985; Moroke et al., 2009; Adindu et al., 2014; Smith, 1972; Musa and Adeoye, 2010 Dixon, 1976; Swartzendruber and Huberly, 1958; Childs and Bybordi, 1969; Carvalho et al., 1999; Berndtsson and Larson, 1987; Kelishadi et al., 2014; Dagadu and Nimbalkar, 2012). Giffobd, (1978) concluded, that it appeared that Kostiakov equation coefficients were related more to vegetation factors than to soil factors based on an analysis of data. Naeth et al., (1991) established that the lower the value of "b", the flatter the slope and thus the lower the rate of decline of infiltration; and the greater the value of "a", the greater the first infiltration value. The equation has no physical basis and is non-homogeneous, but fits very well to the phenomenon of infiltration and has much use in irrigation. The model does not usually give good results for extended periods as observed in practice, which physically is not true and is at odds with the law of Darcy, for a longer time the ground would behave like a saturated medium and "i" should have values close to Kostiakov. A weakness of this model is that it does not predict a constant rate and last infiltration (Mbagwu, 1994). Fok, (1986) showed that the terms "a" and "b" had physical meanings although several authors have described it as empirical. Despite the weaknesses of the model, many researchers have used the model to study the infiltration processes in soils of the temperate and tropical regions (Bonell and Williams, 1986; Lai et al., 1980; Mbagwu, 1987-1990). According to Rondón et al., (1980-1985), the equation had been widely used in irrigation, mainly for its workability; now, several of the equations used in the design of surface irrigation method involve Kostiakov parameters. According to Sonaje, (2013), it describes the infiltration well at minor times but less right at large. No physical interpretation is possible of the constants "a", and "b" since they can only be obtained from field studies and curve-fitting. They cannot be derived from soil physical properties. This attributed to an empirical equation to implicitly account for the effects of factors not considered 
by physical equations. Fok, (1986) derived a set of infiltration equations of the form in which the constants related to the same soil parameters. Drawbacks to the equation are that the constants are dependent on first field conditions such as moisture content and crusting, and determined for each irrigation event. Also, the infiltration rate does not approach a constant value, at large times, which is a commonly accepted notion about infiltration behavior in infiltration practice (Roger, 1993).

\section{MATERIALS AND METHODS}

Sampling for the experimental analysis achieved on a sandy loam savanna soil in Monagas State, Venezuela, situated at a height of 147 meters and geographical coordinates of $9^{\circ} 41^{\prime} 33^{\prime \prime}$ north latitude and $63^{\circ} 23^{\prime}$ west longitude; with an annual rainfall of $1127 \mathrm{~mm}$ and a mean annual temperature of $27.5^{\circ} \mathrm{C}$. Under typical savanna vegetation: Curatella American (Dilleniaceae), Anacardium occidentale, Straw Hairy (Trachypogon and Axonopas sp), Byrsonima crassifolia Malpighiaceae, Hyptis suaveolens Lamiaceae, Grasses and Cyperaceae among others. The soil area selected belongs to a Ultisol group of the family Oxic Paleustults Isohipertérmic in virgin soil conditions. Table 1 shows the physical characteristics and organic matter content. The particle size is in the range established by Rucks et al., (2004) and CIVIL2121 (2012). Figure 1 shows the sampling side position. These soils occupy a large Venezuelan agricultural area engaged in the exploitation of many items, with fertilization, such as maize, sorghum, cassava, and pasture. The lab study achieved in the Soil Physical and Mechanical Laboratory of the University of Oriente, Nucleus of Monagas, Juanico; campus located according to UTM E482908.31 N-1076748.00 and E-482924.24 N1076752.51 .

Table 1. Texture and organic matter analysis. Jusepín, Monagas State.

\begin{tabular}{lcccc}
\hline \multirow{2}{*}{ Components } & \multicolumn{4}{c}{ Horizons (cm) } \\
& $\mathbf{0 - 1 5}$ & $\mathbf{1 5 - 3 0}$ & $\mathbf{4 5 - 6 0}$ & Diameter \\
\cline { 2 - 5 } & $\mathbf{\%}$ & $\mathbf{\%}$ & $\mathbf{\%}$ & $\mathbf{m m}$ \\
\hline Very coarse & 1.01 & 1.31 & 0.20 & 1.41 \\
sand & 6.18 & 5.71 & 2.69 & 0.72 \\
Coarse sand & 19.1 & 14.26 & 13.34 & 0.37 \\
Medium sand & 32.38 & 24.77 & 26.33 & 0.151 \\
Fine sand & 15.0 & 13.11 & 15.81 & 0.07 \\
Very fine sand & 73.67 & 58.66 & 58.37 & \\
Total sand & 16.13 & 17.14 & 29.43 & 0.053 \\
Silt & 10.2 & 24.2 & 12.2 & 0.024 \\
Clay (kaolinite) & 1.20 & 0.61 & 0.45 & \\
Organic matter & SCL & SCL & SCL & \\
Textural class & SCL
\end{tabular}

Source: Labsea, Eudoca, 2010. UDO, Monagas

SCL sandy loam

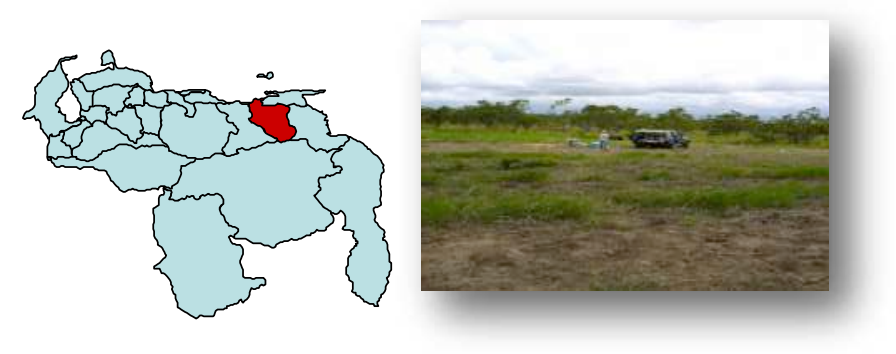

Figure 1. Sampling side position

The experimental unit (Figure 2) consisted of 9 polyvinyl chlorinated cylinders, $15.24 \mathrm{~cm}$ diameter and $20 \mathrm{~cm}$ height. A soil volume of $2.50 \mathrm{~kg} /$ cylinder. Statistical analysis under a randomized block design with three replications; with two factors: humidity with five levels (3, 6, 9, 12 and 15\%) and Proctor compaction with three levels $(0,13$ and 26 blows $)$. The shear tension measurement obtained with a manual in-situ vane shears tension tester (Leiva, 2011; Smith, 2011; Vásquez, 2011).

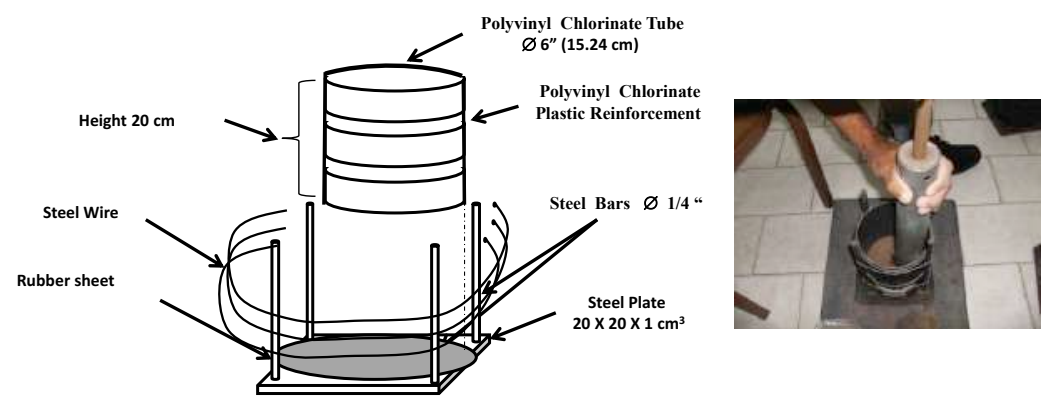

Figure 2. Experimental unit and Proctor tester

The Proctor compaction test is an experimental laboratory method for determining the optimal moisture content at which a given soil type will become most dense and achieve its maximum bulk density. The original test, most commonly called the standard Proctor compaction test (ASTM, 2009).

A piece of tape, stuck on the cylinder wall, with millimeter-scale allowed assessments. The measurements consisted of finding the sheets of infiltrated water into the cylinders, with at least 10 readings per time intervals ranging between 1 and 60 minutes. The regression analyses curve fit and the multiple regression analysis with backward steps were used. The Durbin Watson statistic test autocorrelation always considered between 0 and 4 . If the Durbin-Watson is substantially less than 2, there is evidence of positive correlation. As a rough rule of thumb; if Durbin-Watson is less than 1.0, there may be a cause for alarm. If $>2$, successive error terms are negatively correlated (Montgomery et al., 2001). Table 2 shows the terminology employed. 
Table 2. Terminology employed

\begin{tabular}{ll}
\hline $\mathrm{a}$ and $\mathrm{b}$ & Kostiakov's equation parameters \\
\hline $\mathrm{BL}$ & Block \\
\hline $\mathrm{CO}$ & Compaction blows \\
\hline $\mathrm{CV}$ & Coefficient of variance \\
\hline $\mathrm{DF}$ & Degree of freedom \\
\hline $\mathrm{F}$ & F-statistical significance \\
\hline $\mathrm{i}$ & Infiltration depth \\
\hline $\mathrm{I}_{\mathrm{BA}}$ & Basic infiltration $\mathrm{cm} \cdot \mathrm{h}^{-1}$ \\
\hline $\mathrm{MS}$ & Mean sum of squares \\
\hline $\mathrm{P}$ & $P$-value significance \\
\hline $\mathrm{PR}$ & Soil profiles \\
\hline $\mathrm{SS}$ & Sum of Square \\
\hline $\mathrm{w}$ & Soil wetness \\
\hline $\mathrm{w}_{\mathrm{op}}$ & Optimal wetness \\
\hline$\tau$ & Shear tension \\
\hline$\tau_{\mathrm{op}}$ & Optimal shear tension \\
\hline$\rho_{\mathrm{S}}$ & Bulk density \\
\hline$\rho_{\mathrm{Sop}}$ & Optimal bulk density \\
\hline
\end{tabular}

\section{RESULTS AND DISCUSSIONS}

Se presentarán en un solo capítulo, donde el lector debe The savanna soil terramechanics characteristics, Figure 3, disclose bulk density versus compaction blows, soil wetness, and soil depth, and Figure 4 presents the soil shear tension and bulk density versus soil wetness. This recognizes the wetness influence upon the physical and terramechanical characteristics triggering soil physical variability. These factors affected infiltration. Observe in Figure 4 that at low wetness, the shear tension and bulk density practically did not exist, the soils crumble or powder; the soil particle adhesion (due to water) disappears. Capillary forces can exceed $10 \mathrm{kPa}$ for particles smaller than $0.02 \mathrm{~mm}$ and $1 \mathrm{MPa}$ for particles $<0.0002 \mathrm{~mm}$ (Santamarina, 2001).
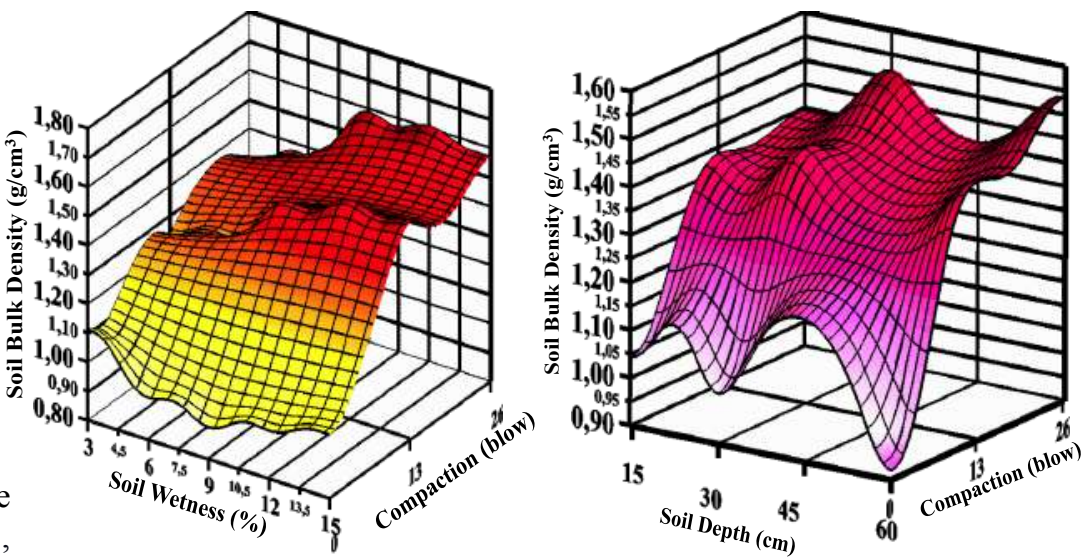

Figure 3. Soil bulk density versus compaction blows, soil wetness and soil depth

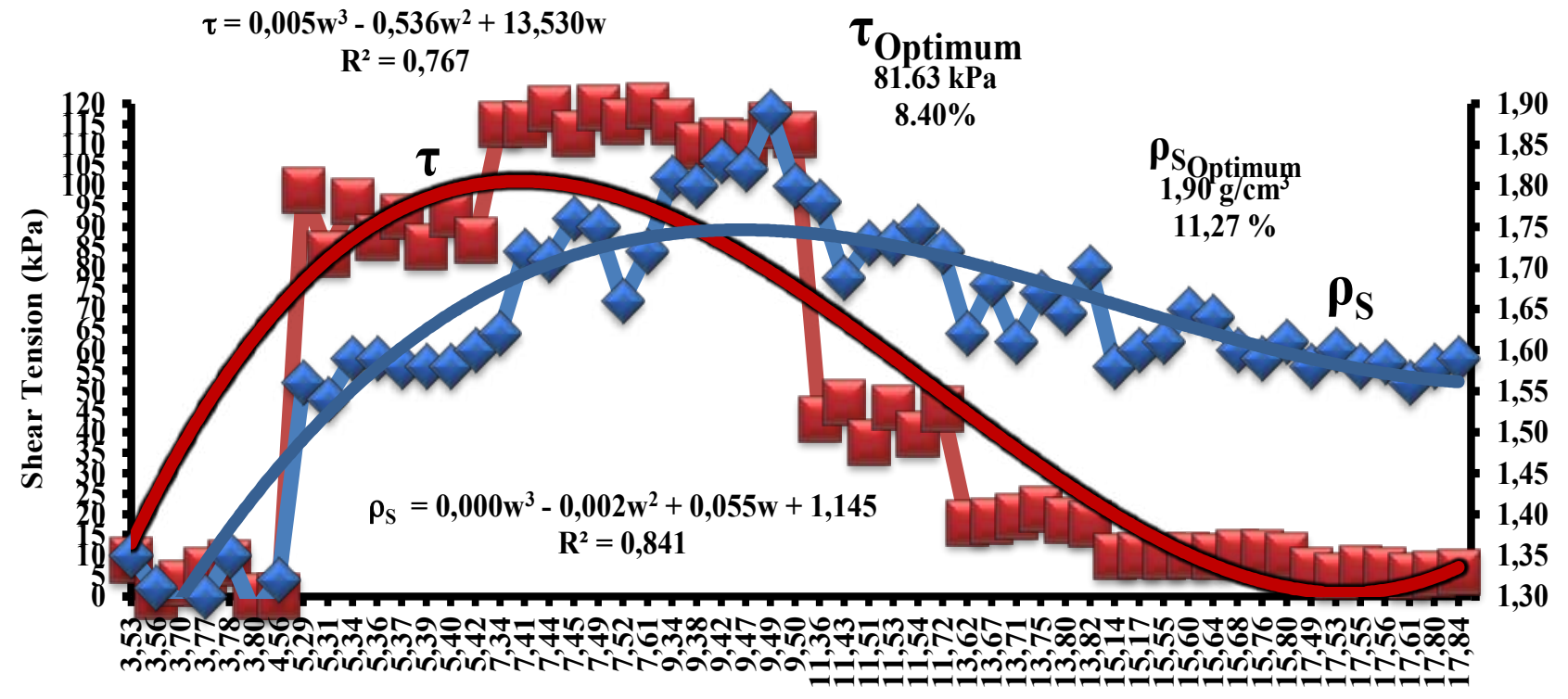

Soil Wetness (\%)

Figure 4. Shear tension and bulk density versus soil wetness for $15 \mathrm{~cm}$ soil profile 
The $\tau$ and $\rho_{\mathrm{S}}$ versus $\mathrm{w}$ presented in Table 3 shows the statistical results where it could be observed effects on Kostikove due to soil structure variability.

Table 3. Regression analysis, with 55 total cases, of $\tau$ and $\rho_{\mathrm{S}}$ versus $\mathrm{w}$

\begin{tabular}{|c|c|}
\hline$\tau$ versus $\mathrm{w}$ & \\
\hline$\tau=19.428 * \mathrm{w}-1.156 * \mathrm{w}^{2}$ & \\
\hline $\begin{array}{l}\mathrm{R}^{2} 79 \% \text {, adjusted } \mathrm{R}^{2} 78 \% \text { Estimated } \\
\text { without constant term }\end{array}$ & $\begin{array}{l}0.0000 \\
\text { ANOVA }\end{array}$ \\
\hline Coefficients significance 0.000 & \\
\hline The optimum value of $\tau_{\text {op }}=81.63 \mathrm{kPa} \mathrm{f}$ & $\mathrm{r}_{\mathrm{op}}=8.40 \%$ \\
\hline$\rho_{\mathrm{S}}$ versus $\mathrm{w}$ regression analysis curve fi & \\
\hline$\rho_{\mathrm{S}}=0.338 * \mathrm{w}-0.015 * \mathrm{w}^{2}$ & \\
\hline $\mathrm{R}^{2} 99 \%$, adjusted $\mathrm{R}^{2} 89.9$ & $\begin{array}{l}0.000 \\
\text { ANOVA }\end{array}$ \\
\hline 0.000 significance for $\mathrm{w}$ and $\mathrm{w}^{2}$ coeffic & \\
\hline$\rho_{\text {Sop }}=1.90 \mathrm{~g} / \mathrm{cm}^{3}$ for $\mathrm{w}_{\mathrm{op}}=11.27 \%$ & \\
\hline
\end{tabular}

Soil infiltration correlated to soil physical and texture exists acknowledged by many studies. Amin (2005) and Michael (2010) noted that the factors affecting infiltration rate (i) of a soil included, among others, the nature of the soil, humus content, soil surface roughness, moisture content, rainfall intensity, vegetation type, and cover, hydraulic characteristics, and permeability (related to soil texture and structure). Failure to consider adequate infiltration process may result in non-uniform distribution of water in the field as well as excessive water loss due to deep percolation and runoff. The antecedent water content of the soil influences the sorptivity or capacity of a soil to absorb (suck up) water. According to Jagdale and Nimbalkar (2012), different soil conditions affect the soil infiltration rate. Compacted soils have a low infiltration rate which is prone to runoff.

The multiple regression analyses for $I_{B A}$ and the independent fitting variables arrangements $a, b, a^{*} b, a^{2}, b^{2}$ and $\mathrm{a}^{*} \mathrm{~b}^{2}$ results are presented in Table 4 showing influences on $\mathrm{I}_{\mathrm{BA}}$

Table 4. Dependent variable $\mathrm{I}_{\mathrm{BA}}$ and the independent variable $a, b, a * b, a^{2}, b^{2}$ and $a^{*} b^{2}$

\begin{tabular}{l|l|l}
\hline $\mathrm{I}_{\mathrm{BA}}=1,02596 * \mathrm{a}+4,07465 * \mathrm{a} * \mathrm{~b}-1,68532 * \mathrm{~b}^{2}+$ \\
$4,47057 * \mathrm{a}^{2} \mathrm{~b}^{2}$ \\
\hline $\mathrm{R}^{2} 99.985$, adjusted & 0.0000 & Durbin- \\
$\mathrm{R}^{2} 99.98 \%$ & ANOVA & Watson 1.43 \\
\hline
\end{tabular}

Coefficients significance 0.000 for all

Greater "a" influence. The "b" values kept practically steady for each value of "a"

The parameters "a" and "b" variability effect on infiltration in a savanna soil, Figures 5, showed a greater "a" influence. The "b" values kept practically steady for each value of "a".

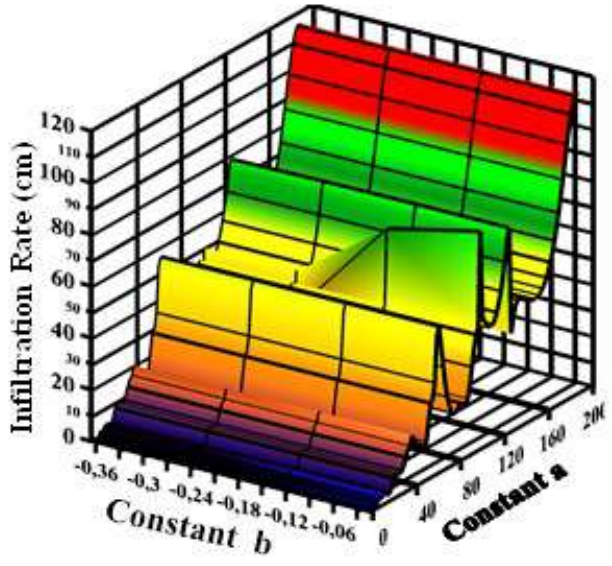

A

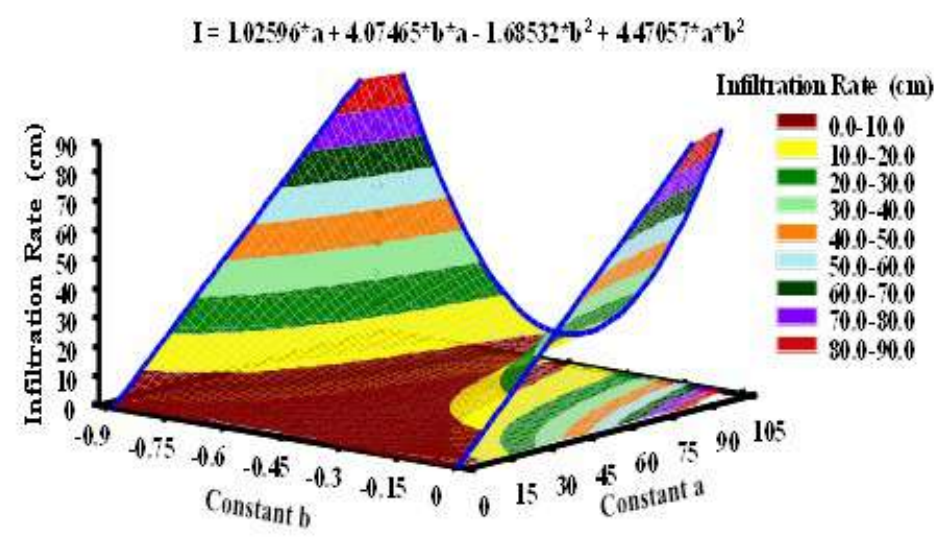

B

Figure 5. The infiltration rate against constants "a", and "b"

Coefficients "a" and "b" fluctuations depend on many factors such as soil type, time, ancient moisture and soil hydraulic conductivity (Azad et al. 2016; Harteli, 1992). According to Weber and Apestegui (2016), if "b" increases, the initial infiltration rate decreases and basic infiltration rate increases; and if "a" increase, both the initial rate and the final infiltration increases. High value parameters models are probably due to high levels of sand
$(75.7 \%)$. The large range of the variation of coefficient "a", demonstrated considerable spatial variability in the studied area (Azad et al. 2016; Duan et al. 2011; Zolfaghari et al. 2012; Mirzaee et al. 2014). Bresler et al. (1984) found that between $24-45 \%$ "a" variability could be related to sand content and 10-25\% explained by the interaction between electrical conductivity and sand amount. Nestor (2006) found for parameter "a", a value of 
76.88 for sandy loam. Adindu et al. (2014) found for some sandy loam soils for " $b$ " values of $-0.48,-0.50,-0.54$, $0.59,-0.62$ and -0.84 , indicating that the soils saturated at that time of the year (wet season); while the 'a' values ranged from $0.35-2.47$. Girei et al. (2016) considered the values of "a", and "b" very high in almost across all the treatments. The higher the value of " $b$ ", the steeper the slope and the greater the rate of infiltration decline. The greater the value of "a", the greater the initial infiltration value (Naeth et al., 1991; Turner, 2006). The value of "b" was consistently less than one. Mbagwu (1990) reported similar findings. Mbagwu (1994) found that the soil properties with the greatest influence over the "a" term are the effective porosity and bulk density. According to Kanya (2007) the value of "a" affects the value of "b" depending on the field data. In this work, "b" as a function of ${ }^{\prime \prime} \mathrm{a}$, resulted $\mathrm{b}=5 \mathrm{E}-07 * \mathrm{a}^{3}-0.0002 * \mathrm{a}^{2}+0.0143 * \mathrm{a}-$
0.3666 with $\mathrm{R}^{2}=80.21 \%$. Musa and Nosa (2003); Lili et al. (2008); Adindu et al. (2014); Azuka et al. (2013); Hunsaker et al. (1999); Zhuo et al. (2009); Mbagwu (1994); Saxton et al., (1986); Michael, (1978); Kanya (2007); Maheshwari (1997); Mazloom and Foladmand (2013); Arab et al. (2014); Adindu et al. (2014); Al-Azawi (1985) noted that soil infiltrability influenced by soil structure, texture, moisture content, initial water content, structure and surface cover conditions, organic matter content, bulk density, clay and fine sand content (texture), wheel furrows, season period, hydraulic conductivity and microporosity contributed immensely to the variation in the infiltration characteristics of the soils.

The "b" ANOVA (Table 5), showed significance with respect to $\mathrm{CO}, \mathrm{w}, \mathrm{PR}, \mathrm{CO} * \mathrm{w}$ and $\mathrm{w}^{*} \mathrm{PR}$

Table 5. Constant "b", analysis of variance for $B L, C O, w, P R$ and the combined effects: $B L * C O, B L * w, B L * P R, C O * w$, CO*PR and $\mathrm{w}^{*} \mathrm{PR}$ of a savanna soil of Monagas State of Venezuela.

\begin{tabular}{|c|c|c|c|c|c|}
\hline Sources & DF & SS & MS & $\mathbf{F}$ & $\mathbf{P}$ \\
\hline Block (BL) & 2 & 0.02376 & 0.01188 & 1.25 & 0.2922 \\
\hline Compaction (CO) & 2 & 0.13147 & 0.06573 & 6.90 & 0.0016 \\
\hline SOIL WETNESS (w) & 4 & 0.63076 & 0.15769 & 16.56 & 0.0000 \\
\hline SOIL DEPTH (PR) & 2 & 0.20237 & 0.10118 & 10.63 & 0.0001 \\
\hline $\mathrm{BL} * \mathrm{CO}$ & 4 & 0.02206 & 0.00552 & 0.58 & 0.6785 \\
\hline $\mathrm{BL}^{*} \mathrm{w}$ & 8 & 0.10931 & 0.01366 & 1.43 & 0.1933 \\
\hline $\mathrm{BL} * \mathrm{PR}$ & 4 & 0.02206 & 0.00552 & 0.58 & 0.6785 \\
\hline $\mathrm{CO} * \mathrm{w}$ & 8 & 0.75621 & 0.09453 & 9.93 & 0.0000 \\
\hline $\mathrm{CO} * \mathrm{PR}$ & 4 & 0.06578 & 0.01645 & 1.73 & 0.1512 \\
\hline W*PR & 8 & 0.21516 & 0.02690 & 2.82 & 0.0078 \\
\hline Error & 88 & 0.83802 & 0.00952 & & \\
\hline Total & 134 & 3.03128 & & & \\
\hline Mean & & & -0.2016 & & \\
\hline $\mathrm{CV}$ & & & & 05 & \\
\hline
\end{tabular}

The multiple regression analysis of $\mathrm{CO}^{*} \mathrm{w}$ effects on the dependent " $b$ " and the independent variables $\mathrm{CO}$, w, $\mathrm{CO}^{*} \mathrm{w}, \mathrm{CO}^{2}, \mathrm{w}^{2}, \mathrm{CO}^{2} * \mathrm{w}, \mathrm{CO}^{*} \mathrm{w}^{2}, \mathrm{CO}^{2} * \mathrm{w}^{2}$, Table 6 and Figure 6 shows that the greatest value for " $b$ " happened for $\mathrm{w}$ and $\mathrm{CO}$ higher values, validated in Table 6 .

Table 6. The multiple regression analysis of $\mathrm{CO}^{*} \mathrm{w}$

\begin{tabular}{l}
\hline The combined effect $\mathrm{CO} * \mathrm{w}$ on the dependent variable "b" \\
\hline $\mathrm{b}=-0.231256 * \mathrm{CO}+0.0382744 * \mathrm{CO}^{2}+0.00017692 * \mathrm{CO}^{2 *} \mathrm{w}^{2}$ \\
\hline $\mathrm{R}^{2} 92.2$, adjusted $\mathrm{R}^{2} 90.79 \%$ \\
without constant term
\end{tabular}

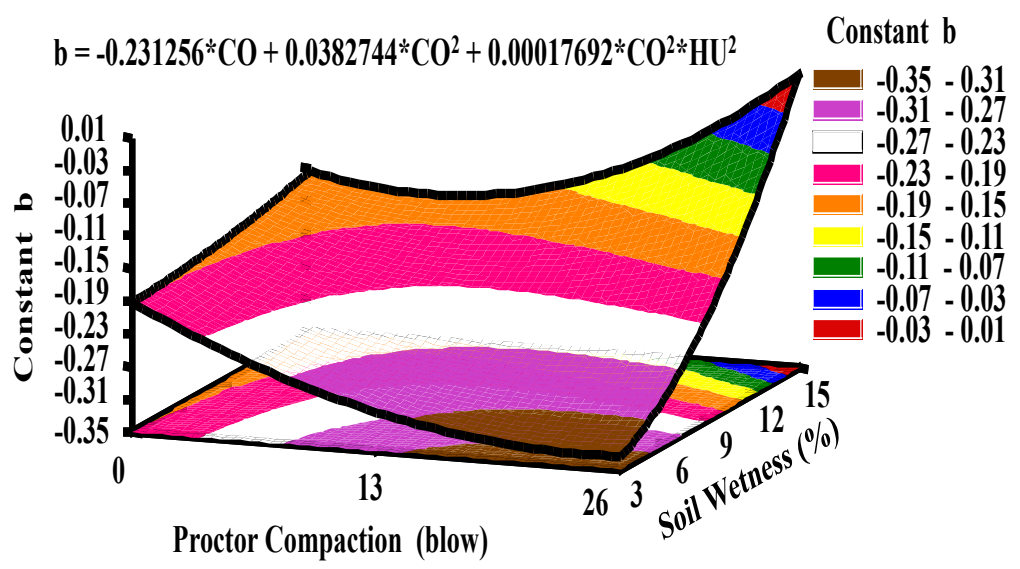

Figure 6. Surface response draft of empirical constant b versus $\mathrm{CO}$ and $\mathrm{w}$ 
The $\mathrm{w}^{*} \mathrm{PR}$ multiple regression analysis and results related with dependent variable " $b$ " and the independent variables $\mathrm{PR}, \mathrm{w}, \mathrm{PR}^{*} \mathrm{w}, \mathrm{PR}^{2}, \mathrm{w}^{2}, \mathrm{PR}^{2} * \mathrm{w}, \mathrm{PR}^{*} \mathrm{w}^{2}, \mathrm{PR}^{2} * \mathrm{w}^{2}$ are presented in Table 7. Figure 7 shows that the greatest value for " $b$ " happened for $15 \%$ wetness and $15 \mathrm{~cm}$ depth, validated in Table 7.

Table 7. The multiple regression analysis of $\mathrm{w} * \mathrm{PR}$

The multiple regression analysis of $\mathrm{w} * \mathrm{PR}$ versus " $\mathrm{b}$ "

$\mathrm{b}=-0.00868566 * \mathrm{w}-0.0105247 * \mathrm{PR}+$

$0.000728146 * \mathrm{~W} * \mathrm{PR}$

\begin{tabular}{l|l}
\hline $\begin{array}{l}\mathrm{R}^{2} \text { 94.72\%, adjusted } \mathrm{R}^{2} 93.83 \% \\
\text { without constant term }\end{array}$ & 0.0000 ANOVA \\
\hline
\end{tabular}

$\mathrm{P}$ significance of $0.0450,0.0000$ and 0.0005 respectively

Durbin-Watson 2.29

In the response surface chart of Figure 7, "b" with respect to $\mathrm{W}$ and $\mathrm{PR}$, with the highest value at $15 \%$ water range for all soil depth. It could be supposed that constant " $b$ " highest values indicated high soil wetness

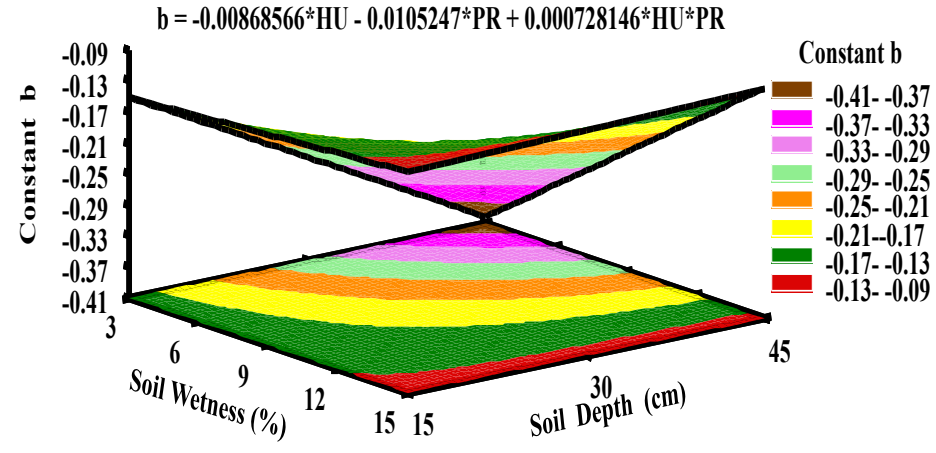

Figure 7. Surface response chart of constant "b" versus soil $\mathrm{W}$ and PR

The "b" indicates how the infiltration rate reduces with time; therefore, it depends on the soil structure changes, resulting from wetting. A small value of " $b$ " indicates that the structure is not stable so the infiltration rate reduced due to structure changes.

The analysis of variance of "a" (Table 8), showed significance with respect to $\mathrm{CO}, \mathrm{w}, \mathrm{PR}, \mathrm{CO} * \mathrm{PR}, \mathrm{CO}^{*} \mathrm{w}$ and $\mathrm{w}^{*} \mathrm{PR}$.

Table 8. Constant "a", analysis of variance for $\mathrm{BL}, \mathrm{CO}, \mathrm{w}, \mathrm{PR}$ and the combined effects: $\mathrm{BL} * \mathrm{CO}, \mathrm{BL} * \mathrm{w}, \mathrm{BL} * \mathrm{PR}, \mathrm{CO} * \mathrm{w}, \mathrm{CO} * \mathrm{PR}$ and $\mathrm{w}^{*} \mathrm{PR}$ of a savanna soil of Monagas State of Venezuela.

\begin{tabular}{|c|c|c|c|c|c|}
\hline \multicolumn{6}{|l|}{ Constant a } \\
\hline Sources & DF & SS & MS & $\mathbf{F}$ & $\mathrm{P}$ \\
\hline Block (BL) & 2 & 185 & 92.5 & 0.44 & 0.6448 \\
\hline Compaction (CO) & 2 & 51226 & 25613.1 & 122.11 & 0.0000 \\
\hline SOIL WETNESS (w) & 4 & 8550 & 2137.4 & 10.19 & 0.0000 \\
\hline SOIL DEPTH (PR) & 2 & 2771 & 1385.5 & 6.61 & 0.0021 \\
\hline $\mathrm{BL} * \mathrm{CO}$ & 4 & 365 & 91.4 & 0.44 & 0.7826 \\
\hline $\mathrm{BL}{ }^{*} \mathrm{w}$ & 8 & 633 & 79.1 & 0.38 & 0.9302 \\
\hline $\mathrm{BL} * \mathrm{PR}$ & 4 & 706 & 176.4 & 0.84 & 0.5029 \\
\hline $\mathrm{CO}^{*} \mathrm{w}$ & 8 & 15120 & 1890.0 & 9.01 & 0.0000 \\
\hline CO*PR & 4 & 9925 & 2481.2 & 11.83 & 0.0000 \\
\hline $\mathbf{w * P R}$ & 8 & 5588 & 698.5 & 3.33 & 0.0023 \\
\hline Error & 88 & 18459 & 209.8 & & \\
\hline Total & 134 & 113527 & & & \\
\hline Mean & & & 21.931 & & \\
\hline $\mathrm{CV}$ & & & & & \\
\hline
\end{tabular}

The multiple regression analysis of $\mathrm{w}^{*} \mathrm{PR}$ effects on the dependent variable " $a$ " and the independent variable: $w$, $\mathrm{PR}, \mathrm{w} * \mathrm{PR}, \mathrm{w}^{2}, \mathrm{PR}^{2}, \mathrm{w}^{2} * \mathrm{PR}, \mathrm{w}^{*} \mathrm{PR}^{2}, \mathrm{w}^{2} * \mathrm{PR}^{2}$ is presented in Table 9. Figure 8 shows that the greatest value for " $\mathrm{a}$ " happened between $9-12 \% \mathrm{w}$ and $15-30 \mathrm{~cm}$ PR, validated in Table 8.
Table 9. The multiple regression analysis of $\mathrm{w}^{*} \mathrm{PR}$ effects on " $a$ "

\begin{tabular}{|c|c|}
\hline \multicolumn{2}{|c|}{$\begin{array}{l}\text { The combined effect } \mathrm{w} * \mathrm{PR} \text { effects on the dependent variable "a" } \\
\mathrm{a}=28.2626 * \mathrm{w}-1.47911 * \mathrm{w} * \mathrm{PR}-1.9994 * \mathrm{w}^{2}+0.0223972 * \mathrm{w}^{*} \mathrm{PR}^{2}+ \\
0.110408 * \mathrm{w}^{2} * \mathrm{PR}-0.0016^{*} \mathrm{w}^{2} * \mathrm{PR}^{2}\end{array}$} \\
\hline $\begin{array}{l}\mathrm{R}^{2} 97.08 \% \text {, adjusted } \mathrm{R}^{2} 95.46 \% \\
\text { without constant term }\end{array}$ & 0.0001 ANOVA \\
\hline \multicolumn{2}{|c|}{$\begin{array}{l}\text { Coefficients significance } 0.001,0.0015,0.0003,0.0026,0.0022 \text {, and } \\
0.0035 \text { respectively }\end{array}$} \\
\hline \multicolumn{2}{|l|}{ Durbin-Watson 1.89} \\
\hline \multicolumn{2}{|c|}{$\begin{array}{l}\text { In the response surface chart, Figure } 8 \text {, "a" varied with respect to } w \\
\text { and slightly with PR, with the highest value around } 15-30 \mathrm{~cm} \text { and } 9 \text { - } \\
12 \%\end{array}$} \\
\hline
\end{tabular}


$\mathrm{a}=28.2626^{*} \mathrm{HU}-1.47911^{*} \mathrm{HU} * \mathrm{PR}-1.9994 * \mathrm{HU}^{2}+0.0223972 * \mathrm{HU}^{*} \mathrm{PR}^{2}+0.110408^{*} \mathrm{HU}^{2} * \mathrm{PR}-0.0016 * \mathrm{HU}^{2 *} \mathrm{PR}^{2}$

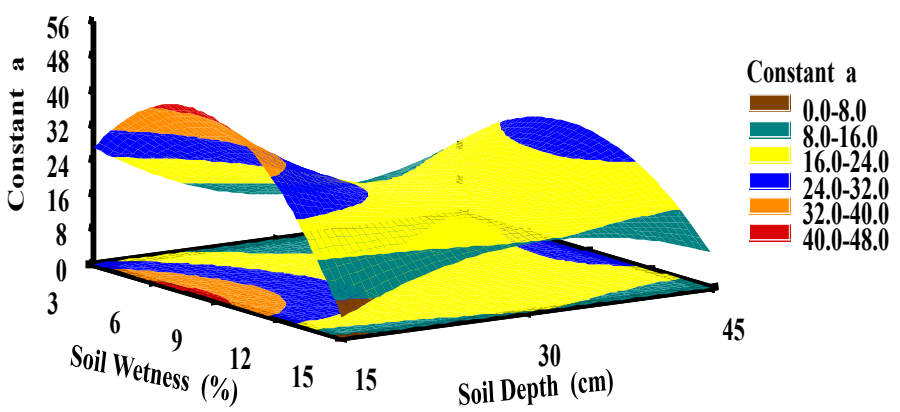

Figure 8. Surface response chart of constant "a" versus w and PR

The CO*PR multiple regression, along with the dependent variable "a", generated a model that included PR, $\mathrm{CO}^{2} * \mathrm{PR}, \mathrm{w} * \mathrm{PR}^{2}$ and $\mathrm{w}^{2} * \mathrm{PR}^{2}$ presented in Table 10 . Figure 9 shows that the greatest value for " $\mathrm{a}$ " happened for $45 \mathrm{~cm}$, and 0 soil CO; also, validated in Table 9.

Table 10. The multiple regression analysis of CO*PR related with " $a$ "

\begin{tabular}{|c|c|}
\hline \multicolumn{2}{|l|}{ Dependent variable "a" versus CO*PR } \\
\hline \multicolumn{2}{|c|}{$0.00203549 * \mathrm{CO}^{*} \mathrm{PR}^{2}+0.000072063 * \mathrm{CO}^{2} * \mathrm{PR}^{2}$} \\
\hline $\begin{array}{l}\mathrm{R}^{2} 99.82 \%, \text { adjusted } \mathrm{R}^{2} 99.68 \% \\
\text { without constant term }\end{array}$ & $\begin{array}{l}0.0000 \\
\text { ANOVA }\end{array}$ \\
\hline \multicolumn{2}{|c|}{$\begin{array}{l}\text { Coefficients significance } 0.0000,0.0021,0.0001 \text { and } \\
0.0002 \text { respectively }\end{array}$} \\
\hline \multicolumn{2}{|l|}{ Durbin-Watson 2.68} \\
\hline \multicolumn{2}{|c|}{$\begin{array}{l}\text { In the response surface chart of Figure } 9 \text {, "a" varies with } \\
\text { respect to CO slightly compared to PR, with the highest } \\
\text { value at } 45 \mathrm{~cm} \text { and } 0 \mathrm{CO}\end{array}$} \\
\hline
\end{tabular}

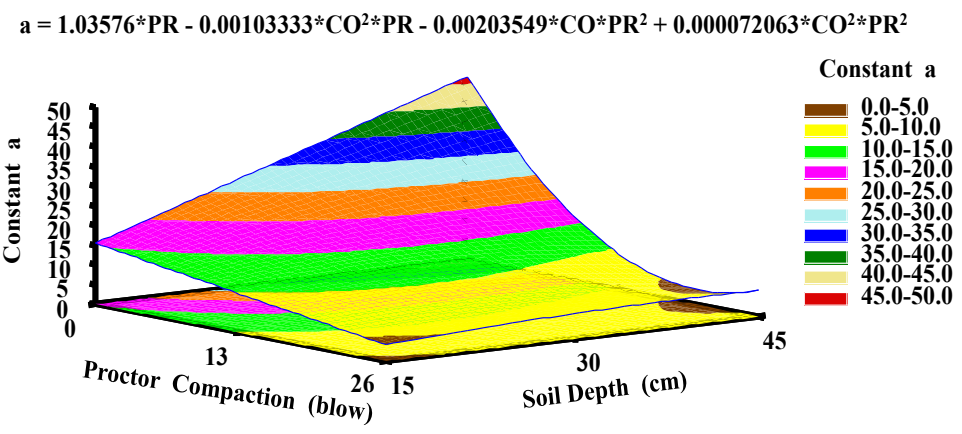

Figure 9. Surface response chart of constant "a" versus CO and PR

The multiple regression analysis of $\mathrm{CO}^{*} \mathrm{w}$ along with the dependent variable " $\mathrm{a}$ ", generated the model $\mathrm{a}=10.68 * \mathrm{w}$ $-1.50 * \mathrm{C} 0 * \mathrm{w}-0.45 *$ presented in Table 11 . Figure 10 shows that the greatest value for "a" happened for $\mathrm{w}$ between 6 and $9 \%$, and 0 CO, validated in Table 10 .
Table11. The multiple regression analysis of $\mathrm{CO}^{*} \mathrm{w}$ along with "a"

Model generated

$\mathrm{a}=10.6762 * \mathrm{w}-1.49969 * \mathrm{CO}^{*} \mathrm{w}-0.445384 * \mathrm{w}^{2}$

\begin{tabular}{llll|l}
\hline $\mathrm{R}^{2}$ & $82.7 \%$, adjusted & $\mathrm{R}^{2}$ & $79.55 \%$ & 0.0001 ANOVA
\end{tabular}

without constant term

Coefficients significance $0.0001,0.0079$ and 0.0036 respectively

Durbin-Watson 2.15

In the response surface chart of Figure 10, "a" varied with respect to $\mathrm{CO}$ slightly compared to $\mathrm{w}$, with the highest value between 6 and $9 \%$ and $0 \mathrm{CO}$

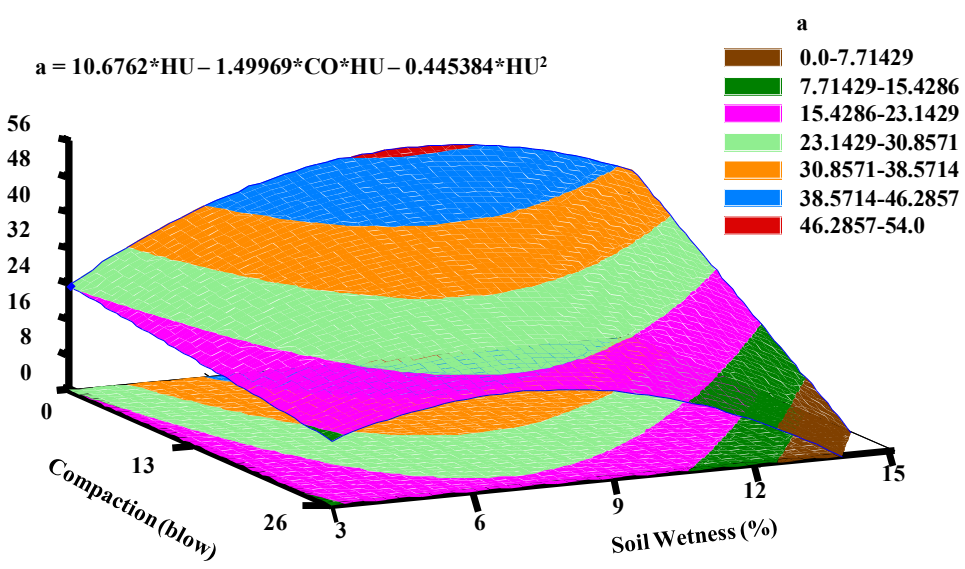

Figure 10. Surface response chart of constant "a" versus $\mathrm{CO}$ and $\mathrm{w}$

The results show that "a" and "b" Kostiakov terms disclosed physical meaning. Fok (1986) showed that the terms of the Kostiakov model have physical meanings even though several authors have described it as empirical. According to Adindu et al. (2014), the infiltration constants decay, including negative values obtained for saturated soils, happened when experiments was conducted under many rains. Do not use freely the equations forms adopted in this study in any soil unless the constants characteristic for that particular soil is first determined. The Durbin Watson statistic tests auto correlation considered, resulted suitable.

\section{CONCLUSIONS}

The parameter "a" showed greater infiltration influence than "b". The "b" values kept practically steady for each value of "a". The parameter " $b$ " decreased with respect to compaction at low wetness; but, increased at higher wetness standards. The relation between the instantaneous infiltration and compaction, infiltration and bulk density were inversely proportional. Wetness influenced inversely shear tension. Compaction influenced " $b$ " more than wetness. Depth influenced " $b$ " more than wetness. Wetness influenced "a" more than depth. Depth 
influenced " $a$ " more than compaction. Wetness influenced "a" more than compaction. Soil texture and soil structure were the properties that most influenced. The greatest value for " $b$ " happened for $15 \%$ wetness and $15 \mathrm{~cm}$ depth. The "a" analysis of variance, showed significance with respect to $\mathrm{CO}, \mathrm{w}, \mathrm{PR}, \mathrm{CO} * \mathrm{PR}, \mathrm{CO}^{*} \mathrm{w}$ and $\mathrm{w}^{*} \mathrm{PR}$. There are not studies deriving the Kostiakov constant from soils physical conditions, but they are influenced by its changes caused by wetness perturbation's.

\section{ACKNOWLEDGMENT}

The authors are grateful to the Research Council and the Agricultural Faculty of the Universidad de Oriente in Venezuela for its support and funding for this research. Three thesis were obtained.

\section{LITERATURE CITED}

Adindu, R.U., Akoma, C.H. and Igbokwe, K.K. 2014. Estimation of Kostiakov's infiltration model parameters of some sandy loam soils of Ikwuano Umuahia, Nigeria. Open Transactions on Geosciences 1(1): 34-38.

Ahuja, L.R., Kozak, J.A., Andales, A.A. and Ma, L. 2007. Scaling parameters of the lewis- kostiakov water infiltration equation across soil textural classes and extension to rain infiltration. American Society of Agricultural and Biological Engineers, 50(5): 15251541 .

Akinbile, C.H.O. 2010. Comparative analysis of infiltration measurements of two irrigated soils in Akure, Nigeria. Advances in Applied Science Research, 1(1): 49-57.

Al-Azawi, S.A. 1985. Experimental evaluation of infiltration models. Journal of Hydrology (N2), 24(2).

Amin, M. 2005. Spatial variability of infiltration in watershed. Journal of Hydrology, 45: 101-122.

Arab, A.I., Mudiare, O.J., Oyebode, M.A. and Idris, U.D. 2014. Performance evaluation of selected infiltration equations for irrigated (FADAMA) soils in Southern Kaduna Plain, Nigeria. Basic Research Journal of Soil and Environmental Science, 2(4): 1-18. ISSN 2345-4090. Available online http//www.basicresearchjournals.org. Copyright (C)2012 Basic Research Journal.

ASTM Standard D1557. 2009. Standard Test Methods for Laboratory Compaction Characteristics of Soil Using Modified Effort, ASTM International, West Conshohocken, PA, DOI: 10.1520/D1557-09.
Azad, B., Fatahi, A.N., Noorolahi, E.M. and Dabiri, D. 2016. Validation of the Kostiakov model to estimate cumulative infiltration in the arid regions of the southwestern Iran. International Journal of Engineering and Advanced Research Technology (IJEART), 2(4): 1-5.

Azuka, C.V., Mbagwu, J.S.C. and Oyerinde, G.T. 2013. Infiltration characteristics and their prediction on a Toposequence at Nsukka, South-Eastern Nigeria. International Journal of Science and Advanced Technology, 3(6): 1-7.

Berndtsson, R. and Larson M. 1987. Spatial variability of infiltration in a semi-arid environment. Journal Hydrology, 90: 117-133.

Bresler, E., Dagan, G., Wagenet, R.J. and Laufer, A. 1984. Statistical analysis of salinity and texture effects on spatial variability of soil hydraulic conductivity. Soil Science Society of America Journal, 48(1): 16-25.

CIVIL2121. 2012. Soil classification. Engineering Geology and Geomechanics. Classification systems based on the US system (The Unified Soil Classification System, USCS), or the British Standard Soil Classification System, The Australian Soil Standard. Http://geotech.uta.edu/lab/main/sieve. $12 \mathrm{p}$. Accessed, February 2012.

Carvalho, J.J., Azevedo, C.A.V., Gomes, E.M., Henrique, J.E. e Neto, D.J. 1999. Efeito das variações espaçotemporais dos parâmetros de Kostiakov-Lewis na infiltração acumulada. Revista Brasileira Engenharia Agrícola e Ambiental, 3(3): 268-275.

Childs, E.C., and Bybordi, M. 1969. The vertical movement of water in stratified porous material, I, Infiltration, Water Resources Research 5(2): 44-59.

Dagadu, J.S. and Nimbalkar, P.T. 2012. Infiltration studies of different soils under different soil conditions and comparison of infiltration models with field data. International Journal of Advanced Engineering Technology, 3(2): 154-157.

Dingman, L. 2002. Water in soils: Infiltration and redistribution. Physical Hydrology. 2nd Ed. Prentice Hall, Upper Saddle River, New Jersey, www.colorado.edu/geography/class.../Notes_8.pdf. $646 \mathrm{pp}$.

Dixon, R.M. 1976. Comment on 'Derivation of an Equation of Infiltration' by H.J. Morel-Seytoux and J. Khanji. Water Resources Research, 12(1): 116118 
Duan, R., Fedler, C.B. and Borrelli, J. 2011. Field evaluation of infiltration models in lawn soils. Irrigation Science, 29: 379-389.

Duru, J.O., HJelmfelt, A.I. and Okereke, N.A.A. 2005. Developments in infiltration theory and applications in hydrologic modeling. Processing of the 6th International Conference of the Nigeria Institution of Agricultural Engineers, Yenagoa, 27; 146-155.

Fok, Y.S. 1986. Derivation of Lewis-Kostiakov intake equation. Journal of Irrigation and Drainage Engineering, 112: 164-171.

Forero, J.A. 2000. Parámetros hidrodinámicos para riego. Universidad Nacional de Colombia. Facultad de Ingeniería. Unidad de Publicaciones. 31p.

Fubara-Manuel, I. and Otoko, G.R. 2015. Adapting the modified Kostiakov empirical cumulative infiltration equation for use in Port Harcourt, Nigeria's Niger Delta. American Research Journal of Civil and Structural Engineering, 1(1):10-16.

Giffobd, G.F. 1978. Use of infiltration equation coefficients as an aid in defining hydrologic impacts of range management schemes. Journal of Range Management, 31(2):115-117.

Girei, A.H., Abdulkadir, A. and Abdu, N. 2016. Goodness of fit of three infiltration models of a soil under longterm trial in Samaru, Northern Guinea Savanna of Nigeria. Journal of Soil Science and Environmental Management, 7(5): 64-72.

Gosh, R.K. 1985. A note on Lewis-Kostiakov's infiltration equation. Soil Science, 139:193-196.

Haghnazari, F., Shahgholi, H. and Feizi, M. 2015. Factors affecting the infiltration of agricultural soils: review. International Journal of Agronomy and Agricultural Research (IJAAR), 6(5): 21-35.

Harteli, E. 1992. Comparison of infiltration models. Soil Science Society of America Journal, (25): 103-114.

Holzapfel, E.A. and Matta, C.R. 2005. Infiltración de agua en el suelo. Universidad de Concepción. Facultad de Ingeniería Agrícola. Departamento de Recursos Hídricos. 30p.

Hunsaker, D.J., Clemmens, A.J. and Fangmeier, D.D. 1999. Cultural and irrigation management effects on infiltration, soil roughness, and advance in furrowed level basins. Transaction of the ASAE, 42(6): 17531762.
Jagdale, S.D. and NImbalkar, P.T. 2012. Infiltration studies of different soils under different soil conditions and comparison of infiltration models with field data. International Journal of Advanced Engineering Technology (IJAET), 3(2): 154-157.

Kanya, L.K. 2007. Toward real-time control of surface irrigation. PhD Dissertation. University of Southern Queensland, Australia. 266 p.

Kelishadi, H., Mosaddeghi, M.R., Hajabbasi, M.A. and Ayoubi, S. 2014. Near saturated soil hydraulic properties as influenced by land use management systems in Koohrang region of central Zagros, Iran. Geoderma, 213: 426-434.

Kincaid, D.C., Heerman, D.F. and Kruse, E.G. 1969. Application rates and runoff in center-pivot sprinkler irrigation. Transactions of the ASAE 12 (6):790-794.

Kostiakov, A.N. 1932. On the dynamics of the coefficient of water-percolation in soils and on the necessity of studying it from a dynamic point of view for purposes of amelioration. Transactions of 6th Congress of International Soil Science Society, Moscow, Part A ,17-21.

Lai, R., Vleeschauwer D.E., D and Nganje, R.M. 1980. Changes in properties of a newly cleared tropical alfisol as affected by mulching, Soil Science Society of American Journal, 44: 827-833.

Leiva, G.L.M. 2011. Relación entre la infiltración y la compactación en el horizonte de 150 a 300 mm de un suelo de sabana, Jusepin del estado Monagas. Trabajo de Grado. Título de Ingeniero Agrónomo. Universidad de Oriente, Núcleo de Monagas, Escuela de Ingeniería Agronómica, Departamento de Ingeniería Agrícola, Maturín, Monagas, Venezuela. Asesores: Américo J. Hossne G., Jesús Méndez Natera y José A. Gil.

Lili, M., Bralts, V.F., Yinghua, P., Han, L. and Tingwu, L. 2008. Methods for measuring soil infiltration: State of the art. International Journal of Agricultural and Biological Engineering, 1(1): 22-30.

Magnus, U.I. and Adindu, R.U. 2014. Use of Kostiakov's infiltration model on Michael Okpara University of Agriculture, Umudike Soils, Southeastern, Nigeria. Journal of Water Resource and Protection, 6: 888894. Published Online July 2014 in SciRes. http://www.scirp.org/journal/jwarphttp://dx.doi.org/ 10.4236/jwarp.2014.610083.

Maheshwari, B.L. 1997. Interrelations among physical and hydraulic parameters of non-cracking soils. 
Journal of Agricultural Engineering Research, 68(4): 297-309.

Mara, R.P. 2016. Planificación y manejo del agua en la agricultura irrigada. Relación suelo-agua. https://dytaguas.files.wordpress.com/. Revisado: 24 febrero 2016. $57 \mathrm{p}$.

Mazloom, H. and Foladmand, H. 2013. Evaluation and determination of the coefficients of infiltration models in Marvdasht region, Fars province. International journal of Advanced Biological and Biomedical Research, 1(8): 822-829.

Mbagwu, J.S.C. 1994. Soil physical properties influencing the fitting parameters in Philip and Kostiakov infiltration models. IC/94/97 Internal Report (Limited Distribution). Atomic Energy Agency W Scientific and Cultural Organization Centre for Theoretical Physics. International Centre for Theoretical Physics, Trieste, Italy. Reviewed: 14 October 2015. 12 p.

Mbagwu, J.S.C. 1990. Mulch and tillage effects on water transmission characteristics of an ultisol and maize grain yield in S.B, Nigeria. Pedologie, 40: 155-168.

Mbagwu, J.S.C. 1987. Effects of land use on the hydrological properties of a southeastern Nigerian soil. Beitrage trop. Landwirtsch. Veterinarmed, 25: 375-382.

MIchael, H. 2010. Abiotic factor. Encyclopedia of Earth. National Council for science and the Environment, Washington D.C.

MIchael, A.M. 1978. Irrigation: Theory and practice. Published Bikas Publishing House PUT Limited, New Delhi. 9 p.

Montgomery, D.C., Peck, E.A. and Vining, G.G. 2001. Introduction to linear regression analysis. 3rd Edition, New York, New York: John Wiley \& Sons.

Mirzaee, S., Zolfaghari, A.A., Gorji, M., Dyck, M. and Ghorbani, D.S. 2014. Evaluation of infiltration models with different numbers of fitting parameters in different soil texture classes. Archives of Agronomy and Soil Science, 60: 681-693.

Moroke, T., Dikinya, O. and Patrick, C. 2009. Comparative assessment of water infiltration of soils under different tillage systems in eastern Botswana. Physics and Chemistry of the Earth, Parts A/B/C, 34(4): 316-323.

Musa, J.J. and Adeoye, P.A. 2010. Adaptability of infiltration equations to the soils of the Permanent
Site Farm of the Federal University of Technology, Minna, in the Guinea savannah zone of Nigeria. AU Journal of Technology, 14: 147-155.

Musa, J.J. and Nosa, A. 2003. Soil grouping of the federal university of technology, minna, main campus farm using infiltration rate. Unpublished M. Eng. Thesis). Federal University of Technology, Minna. 141pp.

Naeth, M.A., Chanasyk, D.S. and Bailey, A.W. 1991. Applicability of the Kostiakov equation to mixed prairie and fescue grasslands of Alberta. Journal of Range Management, 44(1): 18-21.

Negro, V. 1998. Apuntes de infiltración. Universidad Nacional de Lomas de Zamora, Facultad de Ingeniería y Ciencias Agrarias, Cátedra de Hidrología Agraria. 11 p. Revisado enero 2016.

Nestor, L.S.Y. 2006. Modelling the infiltration process with a multi-layer perceptron artificial neural network, Hydrological Sciences Journal, 51(1): 3-20.

Orjuela-Matta, Helber M., Rubiano, S.Y. and CamachoTamayo, J.H. 2010. Comportamiento de la infiltración en un oxisol. Revista UDCA. Actualidad \& Divulgación Científica, 13(2): 31-39.

Poulovassilis, A., Elmaloglou, S., Kerkides, P. and Argyrokastritis, I. 1989. A variable sorptivity infiltration equation. Water Resources Management, 3(4): 287-298.

Rode, A.A. 1965. Theory of soil moisture, Vol. 1 (translated from Russian). Published for USDA and NSF by the Israel Program for Scientific Translation, Jerusalem.

Roger, M.C.H. 1993. Infiltration parameters for mathematical models of furrow irrigation. Thesis. The University of Arizona. 300 North Zeeb Road. Ann Arbor, M1 48106-1346 USA. 313/761-4700 800/521-0600. 147 p.

Rondón, C. Khan P. y Zúnico, R. 1980. Relación aguasuelo-planta-clima. Jusepín, Monagas, Venezuela. Sección Riego y Drenaje, Universidad de Oriente, Escuela de Ingeniería Agronómica, Departamento de Ingeniería Agrícola, estado Monagas, Venezuela.

Rondón, F., Khan P. y Zúnico, H. 1985. Principios de drenaje agrícola. Jusepín, Monagas, Venezuela., Universidad de Oriente, Escuela de Ingeniería Agronómica, Departamento de Ingeniería Agrícola, estado Monagas, Venezuela.

Roy, G.B. and Gosh, R.K. 1982. Infiltration rate at long times, Soil Science, 134: 345-347. 
Rucks, L., García, F., Kaplán, A., Ponce D.E., León J. y Hill, M. 2004. Propiedades físicas del suelo. Universidad De La República, Facultad de Agronomía, Departamento de Suelos y Aguas, Montevideo, Uruguay. 68 p.

Saito, T., Yasuda, H., Suganuma, H., Inosako, K., Abe, Y. and Kojima, T. 2016. Predicting soil infiltration and horizon thickness for a large-scale water balance model in an arid environment. Water 8(3): 1-15.

Santamarina, J.C. 2001. Soil behavior at the microscale: Particle forces. Proceeding Symposium Soil Behavior and Soft Ground Construction, in honor of Charles C. Ladd - October 2001, MIT. E-mail: carlos@ce.gatech.edu. Accessed September 2016. $32 \mathrm{p}$.

Saxton, K., Rawls, W., Romberger, J. and Papendick, R. 1986. Estimating generalized soil-water characteristics from texture. Soil Science Society of America Journal, 50(4): 1031-1036.

Smith, N.I.J. 2011. Relación entre infiltración y compactación en el horizonte de 0 a $150 \mathrm{~mm}$ de un suelo de sabana del estado Monagas. Trabajo de Grado. Título de Ingeniero Agrónomo. Universidad de Oriente, Núcleo de Monagas, Escuela de Ingeniería Agronómica, Departamento de Ingeniería Agrícola, Maturín, Monagas, Venezuela. Asesores: Américo J. Hossne G., Jesús Méndez Natera y José A. Gil.

Smith, R. 1972. The infiltration envelope; results from a theoretical infiltrometer. Journal of Hydrology, 17: $1-21$. http://dx.doi.org/10.1016/00221694(72)90063-7.

Sonaje, N.P. 2013. Modeling of infiltration process - a review. Indian Journal of Applied Research, 3(9): 15.

Swartzendruber, D., and Huberty, M.R. 1958. Use of infiltration equation parameters to evaluate infiltration differences in the field. American Geophysical Union Transaction, 39: 84-93.
Turner, E. 2006. Comparison of infiltration equations and their field validation by rainfall simulation. Thesis submitted to the Faculty of the Graduate School of the University of Maryland, College Park in partial fulfillment of the requirements for the degree of Master of Science.

Vásquez, L.P.A. 2011. Relación entre la infiltración y la compactación en el horizonte de 450 a 600 mm de un suelo de sabana, Jusepín del estado Monagas. Trabajo de Grado. Título de Ingeniero Agrónomo. Universidad de Oriente, Núcleo de Monagas, Escuela de Ingeniería Agronómica, Departamento de Ingeniería Agrícola, Maturín, Monagas, Venezuela. Asesores: Américo J. Hossne G., Jesús Méndez Natera y José A. Gil.

Villalobos, M. 2008. Fundamentos de riego. 1era edición. Cartago: Costa Rica, Ediciones Centro de Desarrollo de Material Bibliográfico (CDMB). 208 p.

Weber, J.F., y Apestegu, L. 2016. Parámetros de los modelos de Kostiakov y Lewis-Kostiakov para áreas permeables del ejido urbano de la ciudad de Córdoba.

jweber@civil.frc.utn.edu.ar.https://www.researchga te.net/publication/266475613. Segundo Taller sobre Estudios Hidrológicos en Regiones Áridas y Semiáridas de la República Argentina. Reviewed: 02 April 2016. 11p.

Zhuo, L., Pute, W., Hao, F., Xining, Z., Jun, H. and Wenhua, Z. 2009. Simulated experiment on effect of soil bulk density on soil infiltration capacity. Transactions of the Chinese Society of Agricultural Engineering, 25(6): 40-46.

Zolfaghari, A., Mirzaee, S. and Gorji, M. 2012. Comparison of different models for estimating cumulative infiltration. International Journal Soil Science, 7: 108-115. 